\title{
Indoxyl sulfate-induced epithelial-to-mesenchymal transition and apoptosis of renal tubular cells as novel mechanisms of progression of renal disease
}

\author{
Su Hyun Kim ${ }^{1, *}$, Min-A Yu ${ }^{2, *}$, Eun Sun Ryu ${ }^{2}$, Yang-Hee Jang ${ }^{2}$ and Duk-Hee Kang ${ }^{2}$
}

Indoxyl sulfate (IS), one of the uremic toxins, is regarded to have a substantial role in the progression of chronic kidney disease (CKD). Epithelial-to-mesenchymal transition (EMT) and apoptosis of renal tubular cells are known to be the critical mechanisms of the development and aggravation of CKD. We investigated the effect of IS on EMT and apoptosis in renal proximal tubular cells, NRK-52E cells. IS significantly inhibited cell proliferation and induced cell migration with a morphological transition from cuboidal epithelial cells to spindle-shaped scattered fibroblast-like cells. IS downregulated the expressions of zonula occluden- 1 and E-cadherin, whereas upregulated $\alpha$-SMA expression at $48 \mathrm{~h}$, which was blocked by a pretreatment of the organic anion transporter, probenecid. IS also induced apoptosis of NRK cells from a concentration of $25 \mu \mathrm{g} / \mathrm{ml}$ with an activation of ERK1/2 and p38 MAP kinase (MAPK). Pretreatment of ERK1/2 or p38 MAPK inhibitors, PD98059 or SB203580, resulted in no significant effect on IS-induced EMT, whereas it ameliorated IS-induced apoptosis of NRK cells. These findings suggested phenotypic transition and apoptosis as potential mechanisms of IS-induced renal damage and the differential role of MAPK activation in IS-induced EMT and apoptosis of renal tubular cells.

Laboratory Investigation (2012) 92, 488-498; doi:10.1038/labinvest.2011.194; published online 9 January 2012

KEYWORDS: apoptosis; chronic kidney disease; epithelial-to-mesenchymal transition; indoxyl sulfate; MAPKinase

Indoxyl sulfate (IS) is one of the protein-bound uremic solutes derived from tryptophan, which is converted to indole and subsequently undergoes sulfate conjugation in hepatocytes to form IS. ${ }^{1}$ It is taken by organic anion transporters (OATs) at the basolateral membrane of proximal tubular cells, and excreted mostly into urine through tubular secretion. ${ }^{2}$ Therefore, IS accumulates in patients with chronic kidney disease (CKD), ${ }^{3}$ demonstrated as an increase in serum level and positive immunostaining area of IS in the kidneys. ${ }^{4}$ Although IS is regarded as a marker of renal dysfunction, recent data have revealed that IS also has a substantial role in the progression of CKD. ${ }^{5}$ Indole, the precursor of IS, caused glomerular sclerosis in uremic rats, ${ }^{6}$ and oral administration of IS increased serum creatinine and decreased inulin clearance in uremic rats. ${ }^{3}$ In a clinical study, patients with urinary IS levels $>90 \mathrm{mg} /$ day showed faster progression rate of CKD than did those with urinary IS $<30 \mathrm{mg} /$ day. ${ }^{7}$ Furthermore, the administration of oral adsorbent of IS resulted in a decrease in glomerular sclerosis and interstitial fibrosis in uremic rats associated with a decrease in plasma and urinary IS levels. ${ }^{3}$ Lowering IS also resulted in an improvement of renal function and a delay in the initiation of dialysis in CKD patients. $^{8}$ In a multicenter, randomized clinical study, Schulman et $a l^{9}$ showed that an administration of AST-120, oral adsorbent of IS, ameliorated uremic symptoms in a dose-dependent manner with a decrease in serum IS and a stable maintenance of serum creatinine. The mechanism of IS-induced renal progression has been explained by an activation of profibrotic cytokines, an induction of oxidative stress and inflammatory mediators. ${ }^{10}$

Recent studies have demonstrated the role of phenotypic transition of renal tubular cells in the progression of kidney disease. Epithelial-to-mesenchymal transition (EMT), one of these phenotypic transitions, has been recognized to have pivotal roles in the development and/or aggravation of CKD despite recent debates. ${ }^{11,12}$ Apoptosis of renal tubular cells is

\footnotetext{
${ }^{1}$ Division of Nephrology, Department of Internal Medicine, Chung-Ang University, Seoul, Korea and ${ }^{2}$ Division of Nephrology, Department of Internal Medicine, Ewha Medical Research Center, Ewha Woman's University School of Medicine, Seoul, Korea

Correspondence: Dr D-H Kang, MD, Division of Nephrology, Ewha University School of Medicine, 911 Mok-dong Yangchun-ku, Seoul 158-710, Korea.

E-mail: dhkang@ewha.ac.kr

*These authors contributed equally to this work.

Received 10 May 2011; revised 13 October 2011; accepted 26 October 2011
} 
also known to contribute to the regulation of renal cell number with an induction and repair of renal injury. ${ }^{13}$ Both EMT and apoptosis are major mechanisms of renal injury; however, there have been few studies investigating whether IS-induced renal injury is related to EMT and/or apoptosis of renal tubular cells.

In this study, we examined whether IS per se induced EMT and apoptosis in cultured renal proximal tubular cells, and explored the potential intracellular signaling pathways responsible for IS-induced phenotypic transition and/or death of renal cells.

\section{MATERIALS AND METHODS Reagents}

All chemicals and tissue culture plates were obtained from Sigma-Aldrich, St Louis, MO, USA) and Nunc Labware (Waltham, MA, USA), unless otherwise stated.

\section{Cell Culture}

Rat renal tubular epithelial cells (NRK-52E cells) were obtained from the American Type Culture Collection (ATCC, Manassas, VA, USA). NRK-52E cells were cultured in Dulbecco's modified Eagle's medium (DMEM) supplemented with $5 \%$ fetal bovine serum (FBS), and $60 \mu \mathrm{g} / \mathrm{ml}$ penicillin. Cells were maintained at $37^{\circ} \mathrm{C}$ in a humidified $5 \%$ $\mathrm{CO}_{2} / 95 \%$ air atmosphere incubator. A fresh growth medium was added to the cells every 2 days until cells reached an adequate confluency for each experiment.

\section{Cytotoxicity Assay}

Cytotoxicity of IS in NRK-52E cells was determined by the amount of lactate dehydrogenase (LDH) leakage into the medium at 48,72 , and $96 \mathrm{~h}$ of IS stimulation $(6.25-125 \mu \mathrm{g} / \mathrm{ml})$ using LDH cytotoxicity detection kit (Roche, Mannheim, Germany). Cytotoxicity was expressed as the percentage of LDH released from IS-stimulated cells to total $\mathrm{LDH}$ from cell lysates. Each series of data was determined in triplicate $(N=5)$.

\section{Cell Proliferation Assay: $\left[{ }^{3} \mathrm{H}\right]-$ Thymidine Incorporation Assay}

The NRK cell was cultured at a concentration of $5 \times 10^{4}$ cells/ $\mathrm{ml}$ in 6-well tissue culture plates in DMEM containing 5\% FBS. Cells were incubated with IS (from 6.25 to $125 \mu \mathrm{g} / \mathrm{ml}$ ) at $37^{\circ} \mathrm{C}$ for $48-96 \mathrm{~h}$, and then $\left[{ }^{3} \mathrm{H}\right]$-thymidine $(1 \mu \mathrm{Ci} / \mathrm{ml})$ was added. After washing with trichloroacetic acid and phosphate-buffered saline (PBS), cells were solubilized with $2 \%$ SDS before quantitation of $\left[{ }^{3} \mathrm{H}\right]$ by scintillation counting (Beckman Coulter). Data from each experimental condition were derived from triplicate $(N=5)$.

\section{Cell Migration Assay}

Cell migration was evaluated as one of the indicators of phenotypic transition. NRK cells were seeded onto the upper chamber of each Transwell (Corning Costar, NJ, USA) at a density of $2 \times 10^{5}$ cells/ml. In $4 \mathrm{~h}$ after seeding, the upper chamber was transferred to the lower chamber plate containing the IS ( 25 or $50 \mu \mathrm{g} / \mathrm{ml}$ ) and incubated in a humidified incubator with $5 \% \mathrm{CO}_{2}$ at $37^{\circ} \mathrm{C}$ for $24 \mathrm{~h}$. Non-migratory cells were then scraped off from the top of the Transwell with a cotton swab and cells attached to the bottom side of the Transwell membrane was fixed by $4 \%$ paraformaldehyde, and stained with hematoxylin. Cells were counted in five non-overlapping $\times 10$ fields using a phase-contrast microscope (Olympus CK 30). The experiments were performed in triplicate $(N=5)$.

Cell Morphology and Fluorescent Immunocytochemistry After stimulation with IS at concentrations from 6.25 to $50 \mu \mathrm{g} / \mathrm{ml}$ for $24-48 \mathrm{~h}$, morphological changes of NRK-52E cells were examined under an inverted phase-contrast microscope (Axiovert 200; Carl Zeiss, Oberkochen, Germany), and images were obtained by digital camera (AxioCam HRC; Carl Zeiss). For immunofluorescence staining, cells were washed and fixed in $4 \%$ phosphate-buffered paraformaldehyde $\left(25 \mathrm{~min}\right.$ at $\left.20^{\circ} \mathrm{C}\right)$ and permeabilized with $1 \%$ Triton $\mathrm{X}-100$ in PBS $\left(15 \mathrm{~min}\right.$ at $\left.4^{\circ} \mathrm{C}\right)$. After washing with PBS and blocking with $5 \%$ BSA for $1 \mathrm{~h}$, cells were incubated with primary antibodies specific for zonula occluden-1 (ZO-1) (Invitrogen, CA, USA) or $\alpha$-smooth muscle actin ( $\alpha$-SMA, Sigma-Aldrich) in $5 \%$ BSA overnight at $4^{\circ} \mathrm{C}$, followed by incubation with goat anti-mouse IgG-FITC-conjugated secondary antibody (Santa Cruz Biotechnology, CA, USA) for $1 \mathrm{~h}$ at room temperature in the dark. The nucleus was counter-stained with DAPI, and cells were visualized under the Axiovert 200 fluorescence microscope (Carl Zeiss).

\section{Western Blot Analysis}

After incubation of renal tubular cells with IS for $48 \mathrm{~h}$ to 7 days, protein samples isolated from cell lysates were mixed in reducing buffer, boiled, resolved on 10\% SDS-PAGE gels, and transferred to a polyvinylidene difluoride membrane by electroblotting as described previously. ${ }^{14}$ Membranes were blocked in 5\% wt $/ \mathrm{vol}$ nonfat milk powder in Tris-buffered saline for $30 \mathrm{~min}$ at room temperature. Blots were then incubated overnight in blocking solution with primary antibody at $4{ }^{\circ} \mathrm{C}$. Mouse $\mathrm{mAb}$ to human E-cadherin (BD Bioscience, Bedford, MA, USA) and human $\alpha$-SMA were used. After washing the blot with Tris-buffered saline with Tween 20, the blots were incubated with alkaline phosphatase-conjugated secondary antibodies corresponding to each primary antibody, followed by enhanced chemiluminescence detection (Santa Cruz Biotechnology). Positive immunoreactive bands were quantified by densitometry and compared with the expression of $\beta$-actin.

To examine the activation of ERK1/2 and p38 MAP kinase (MAPK), cells were incubated with IS $(25 \mu \mathrm{g} / \mathrm{ml})$ for 5-120 min before harvesting the protein, and subjected to western blot analysis of ERK1/2, p-ERK1/2 (Santa Cruz Biotechnology), p38, and p-p38 (Santa Cruz Biotechnology). 


\section{Real-Time PCR}

The levels of E-cadherin and $\alpha$-SMA transcripts were determined by real time PCR (RT-PCR) on the ABI PRISM 7000 sequence detection system using SYBR Green I as a double-stranded DNA-specific dye according to the manufacturer's instructions (Applied Biosystems, Foster City, CA, USA). The PCR reaction was carried out in $5 \mu \mathrm{l}$ cDNA, $10 \mu \mathrm{l}$ of SYBR Green PCR master mix, and $5 \mathrm{pM}$ of sense and antisense primers of E-cadherin or $\alpha$-SMA (Table 1) for a final volume of $20 \mu \mathrm{l}$ per reaction. Primer concentrations were determined by preliminary experiments that analyzed the optimal concentrations of each primer. The relative mRNA expression levels of the target genes in each sample were calculated using the comparative $\mathrm{C}_{\mathrm{T}}$ method. The $\mathrm{C}_{\mathrm{T}}$ value is the cycle number at which the fluorescence signal is greater than a defined threshold. At least three independent PCR procedures were performed to allow statistical analysis. The amount of PCR products was normalized with the house-keeping gene, $\beta$-actin, to determine the relative expression ratios for each mRNA in relation to the control group.

\section{Cell Apoptosis Assay: Flow Cytometric Analysis for PI Staining and Annexin V-FITC Binding}

After exposure of NRK cells to IS for $48 \mathrm{~h}$, cell suspensions $\left(1 \times 10^{6}\right.$ cells $)$ were prepared by treating cells with trypsin/ EDTA mixture in DMEM. Cells were washed twice in cold PBS, and then resuspended in $1 \times$ Annexin V binding buffer at a concentration of $1 \times 10^{6}$ cells $/ \mathrm{ml}$. After incubation of $100 \mu \mathrm{l}$ cell suspension with $5 \mu \mathrm{l}$ FITC Annexin V and $5 \mu \mathrm{l}$ propidium iodide $(\mathrm{PI})$ at room temperature $\left(25^{\circ} \mathrm{C}\right)$ in the dark for $15 \mathrm{~min}, 400 \mu \mathrm{l}$ of $1 \times$ binding buffer was added to each tube. Samples were then analyzed on a FACS Calibur flow cytometer (Beckton Dickinson, San Jose, CA, USA) and CellQuest software (Beckton Dickinson). Early and late apoptosis were assessed by measuring the fraction of Annexin $\mathrm{V}+/ \mathrm{PI}-$ and Annexin $\mathrm{V}+/ \mathrm{PI}+$ cells, respectively.

\section{Effects of the Inhibitors of OAT, ERK1/2 or p38 MAPK}

To determine whether the effect of IS on EMT and apoptosis required uptake of IS into the cell, cells were pretreated with probenecid $(1 \mathrm{mM})$, an inhibitor of an OAT, which blocked the entry of IS into renal tubular cells for $30 \mathrm{~min}$, and stimulated with IS $(25 \mu \mathrm{g} / \mathrm{ml})$. We also investigated the effect of inhibitors of the ERK1/2 inhibitor (PD98059, $10 \mu \mathrm{M}$ ) or the p38 inhibitor (SB203589, $10 \mu \mathrm{M}$ ) on IS-induced EMT and apoptosis.

\section{Statistical Analysis}

All data are presented as mean \pm s.d. Differences in the various parameters between groups were evaluated by twoway ANOVA, followed by correction for Turkey's multiple comparison analysis. Results were considered significant if the $P$-value was $\leq 0.05$.

\section{RESULTS \\ Effect of IS on Cell Proliferation, Cytotoxicity, and Migration in NRK-52E Cells}

No significant cytotoxicity was assessed by LDH release in IS-stimulated cells at concentrations of $6.25-25 \mu \mathrm{g} / \mathrm{ml}$ (Figure 1). Exposure of NRK-52E cells to IS for 48, 72, and 96 hours resulted in an inhibition of proliferation by $>60 \%$ as compared with control from a concentration of $6.25 \mu \mathrm{g} / \mathrm{ml}$. Despite a significant inhibition of cell proliferation by IS, IS promoted cell migration, one of the characteristics of EMT of renal tubular cells (Figure 2).

\section{Morphological Changes in NRK-52E Cells}

Unstimulated NRK-52E cells displayed typical cobblestone morphology of epithelial cells when grown in culture medium (Figure 3). IS induced morphological changes from $48 \mathrm{~h}$ of stimulation in NRK-52E cells, which became elongated in shape forming a fibroblast-like morphology with a loss of cell-to-cell contact compared with control cells (Figure 3).

\section{Effect of IS on the Expression of ZO-1, E-Cadherin, and $\alpha$-SMA}

In association with morphological transformation, we also examined the expressions of ZO-1 as an indication of tightjunction integrity and $\alpha$-SMA as an indicator of transition to a mesenchymal phenotype. As shown in Figure 4, there was abundant cellular expression of ZO-1 mainly at the cell membrane in unstimulated renal tubular cells, whereas both membranous and cytoplasmic expression of ZO-1 were much decreased in IS-stimulated cells (Figure 4b). In addition, IS upregulated $\alpha$-SMA organization (Figure 4d) contrasting with nearly negative staining in untreated cells (Figure 4c).

Western blot analysis also demonstrated IS-induced alteration in the expression of E-cadherin and $\alpha$-SMA. With $25 \mu \mathrm{g} / \mathrm{ml}$ of IS, expressions of E-cadherin were decreased to

Table 1 Real-time PCR primer sequence

\begin{tabular}{llll}
\hline Gene symbol & Accession no. & Forward primer $\left(5^{\prime}-3^{\prime}\right)$ & Reverse primer $\left(5^{\prime}-3^{\prime}\right)$ \\
\hline E-Cadherin & NM_031334 & AACGAGGGCATTCTGAAAACA & CACTGTCACGTGCAGAATGTACTG \\
$\alpha$-SMA & NM_031004 & GACCCTGAAGTATCCGATAGAACA & CACGCGAAGCTCGTTATAGAAG \\
$\beta$-Actin & EF156276 & AGGGAAATCGTGCGTGAC & CGCTCATTGCCGATAGTG \\
\hline
\end{tabular}



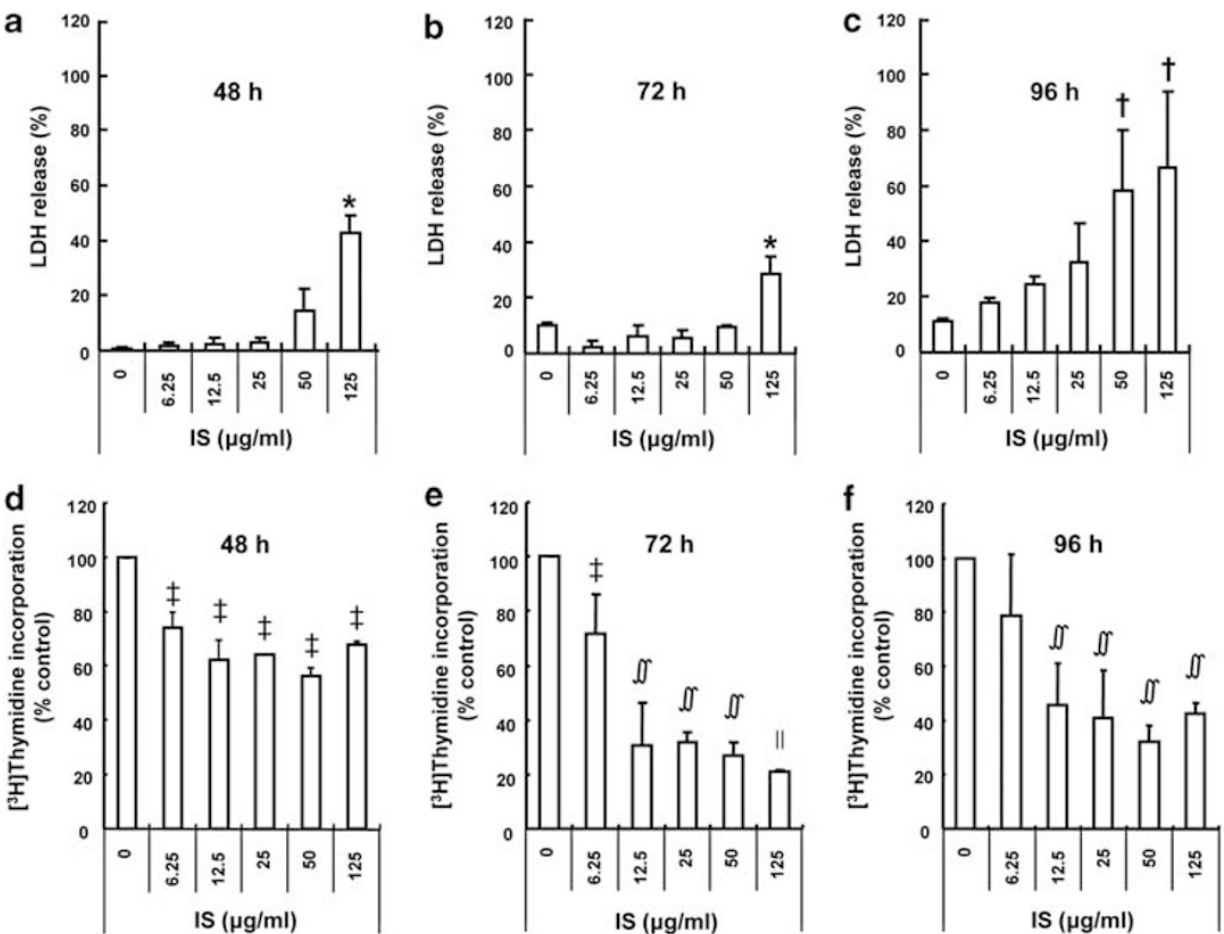

Figure 1 Effect of IS on cytotoxicity and proliferation of NRK-52E cells. IS at concentrations from 6.25 to $50 \mu \mathrm{g} / \mathrm{ml}$ did not induce significant increase in $\mathrm{LDH}$ release at $48 \mathrm{~h}(\mathbf{a})$ and $72 \mathrm{~h}(\mathbf{b})$. IS at a concentration of $125 \mu \mathrm{g} / \mathrm{ml}$ induced a significant cytotoxicity at 48 and $72 \mathrm{~h}$, whereas IS at concentrations $\geq 50 \mu \mathrm{g} / \mathrm{ml}$ induced a significant increase of LDH release at $96 \mathrm{~h}$ (c). IS significantly inhibited the growth of cells from a concentration of $6.25 \mu \mathrm{g} / \mathrm{ml}$ at $48 \mathrm{~h}(\mathbf{d})$ and $72 \mathrm{~h}(\mathbf{e})$ of stimulation. IS at a concentration $\geq 12.5 \mu \mathrm{g} / \mathrm{ml}$ significantly inhibited the growth of NRK-52E cells at $96 \mathrm{~h}(\mathbf{f})$. ( $N=5$ ),

${ }^{\star} P<0.01 \mathrm{vs}$ others at each time point; ${ }^{\dagger} P<0.05$ vs $0-25 \mu \mathrm{g} / \mathrm{ml}$ of IS; ${ }^{\ddagger} P<0.05 \mathrm{vs} 0 \mu \mathrm{g} / \mathrm{ml}$ of IS; ${ }^{\iint P<0.05 \mathrm{vs}} 6.25 \mu \mathrm{g} / \mathrm{ml}$ of IS; ${ }^{\|} P<0.05 \mathrm{vs} 12.5-50 \mu \mathrm{g} / \mathrm{ml}$ of IS.

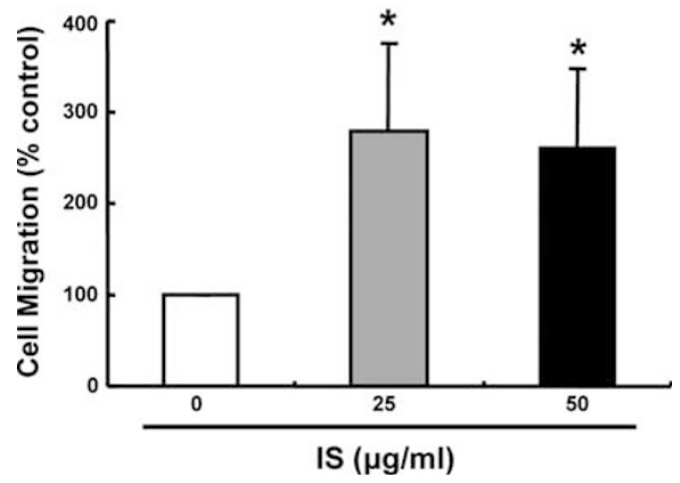

Figure 2 Effect of IS on migration of NRK-52E cells. IS at concentrations of 25 and $50 \mu \mathrm{g} / \mathrm{ml}$ promoted the migration of NRK-52E cells $(N=5)$. ${ }^{*} P<0.05$ vs $0 \mu \mathrm{g} / \mathrm{ml}$ of IS.

$\sim 60$ and $40 \%$ of those in untreated cells at $48 \mathrm{~h}$ and 7 days, respectively $(P<0.05)$ (Figure $5 \mathrm{a}$ and $\mathrm{b})$. In addition, IS from a concentration of $6.25 \mu \mathrm{g} / \mathrm{ml}$ markedly upregulated $\alpha$-SMA expression at $48 \mathrm{~h}$ and 7 days in dose- and time-dependent manners $(P<0.05)$ (Figure $5 \mathrm{a}$ and $\mathrm{c})$. Importantly, pretreatment with probenecid $(1 \mathrm{mM})$ significantly blocked ISinduced changes in the expression of E-cadherin and $\alpha$-SMA in NRK-52E cells $(P<0.05 v s$ IS-treated cells), suggesting that IS per se entering into cells was responsible for IS-induced
EMT (Figure 6). mRNA expression of E-cadherin and $\alpha$-SMA assessed by quantitative RT-PCR showed the similar findings with western blotting (Figure 7).

\section{Effect of IS on Apoptotic Cell Death in NRK-52E Cells}

Interestingly, IS per se induced an early apoptosis of NRK-52E cells from a concentration of $25 \mu \mathrm{g} / \mathrm{ml}$ at $48 \mathrm{~h}$ of stimulation $(36.3 \pm 3.7 \%$ vs $15.2 \pm 5.2 \%, P<0.05)$, which was significantly ameliorated with pretreatment of probenecid (Figure 8). The fraction of late apoptosis was negligible with no significant difference between IS-stimulated NRK cells and control.

\section{IS Induced an Activation of ERK1/2 and p38 MAPK}

To further understand the responsible mechanisms of ISinduced EMT in renal tubular cells, we investigated the activation of ERK1/2 and p38 MAPK signaling pathways by IS stimulation. The increase in ERK1/2 phosphorylation was observed at $5 \mathrm{~min}$, peaked at $10 \mathrm{~min}(P<0.05$ vs $0 \mathrm{~min})$ (Figure 9a and b). The increase in $\mathrm{p} 38$ phosphorylation was also observed at $10 \mathrm{~min}(P<0.05$ vs $0 \mathrm{~min})$ (Figure $9 \mathrm{c}$ and d).

\section{Effect of MAPK Inhibitor on IS-Induced EMT and Apoptosis}

Although IS significantly activated ERK $1 / 2$ and p38 MAPK, neither the ERK1/2 inhibitor (PD98059, $10 \mu \mathrm{M}$ ) nor the p38 


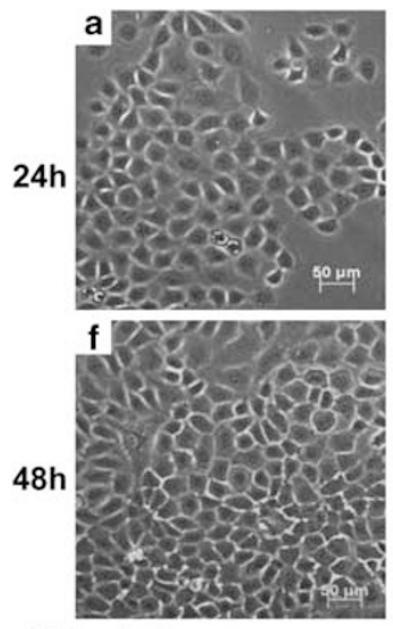

IS $(\mu \mathrm{g} / \mathrm{ml})$
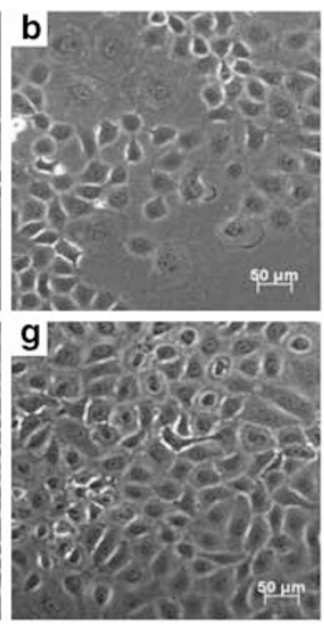

6.25
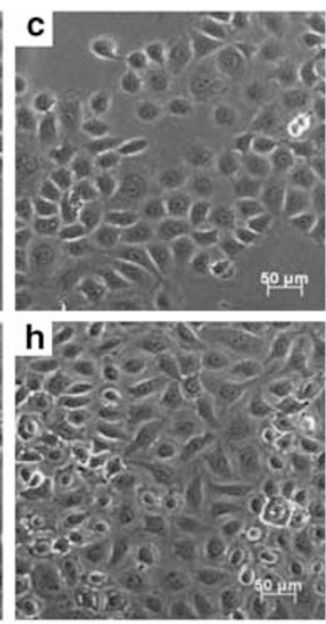

12.5
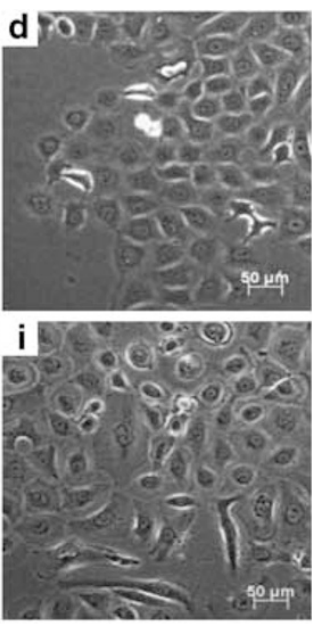

25
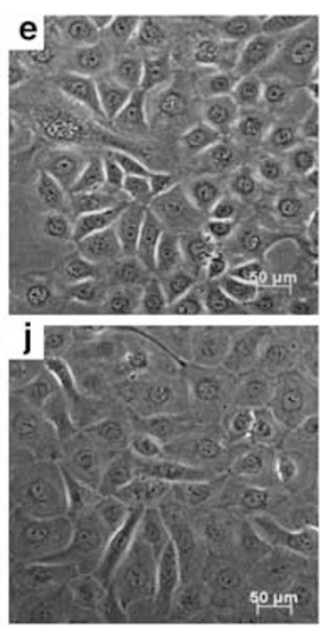

50

Figure 3 Effect of IS on cell morphology in NRK-52E cells. Unstimulated NRK-52E cells displayed typical cobblestone appearance at $24 \mathrm{~h}$ (a) and $48 \mathrm{~h}$ (f). Exposure to IS induced a phenotypic transition from cuboidal clustered epithelial cells to elongated-shaped fibroblast-like cells from concentrations $\geq 6.25 \mu \mathrm{g} / \mathrm{ml}$ (g) at $48 \mathrm{~h}$ with a loss of cell contacts (panels $\mathbf{g}-\mathbf{j}$ ). At $24 \mathrm{~h}$, similar morphological changes, but less prominent compared with $48 \mathrm{~h}$, were noted in IS-stimulated cells $(\mathbf{b}-\mathbf{e})$. Magnifications: $\times 100$ in panels a through $\mathbf{j}$.
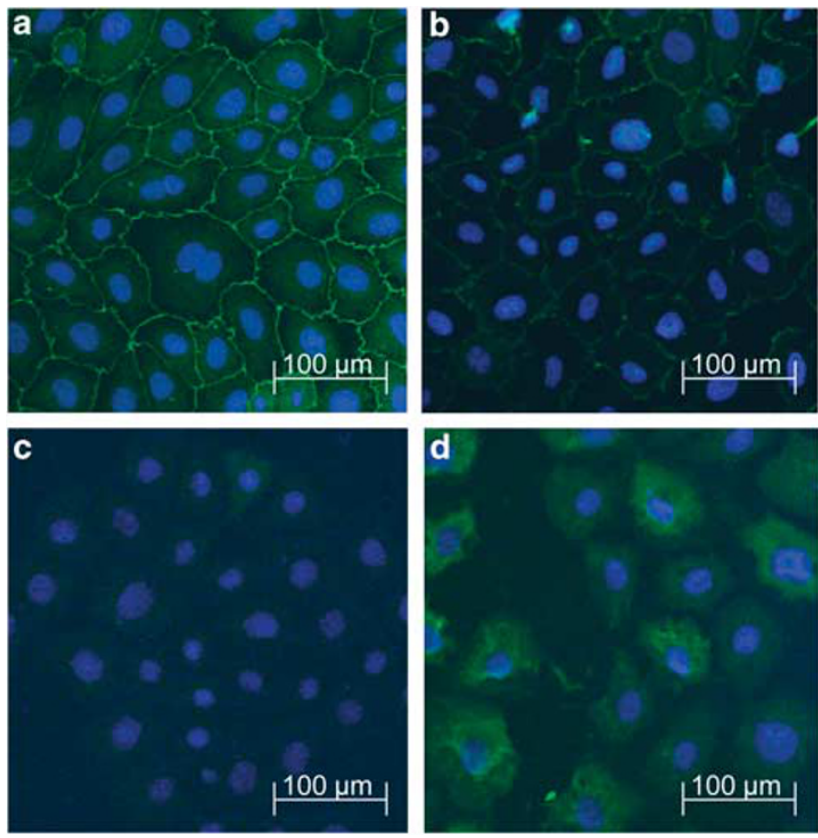

Figure 4 Fluorescence immunocytochemistry for ZO-1 and $\alpha$-SMA in NRK-52E cells. Untreated NRK-52E cells exhibited abundant ZO-1 expression (a) and negligible $\alpha$-SMA expression (c). After treatment with IS of $25 \mu \mathrm{g} / \mathrm{ml}$, ZO-1 immunoreactivity was decreased (b), whereas $\alpha$-SMA immunoreactivity was substantially increased (d) after $48 \mathrm{~h}$. Magnifications: $\times 100$ in panels a through $\mathbf{d}$.

inhibitor (SB203589, $10 \mu \mathrm{M})$ ameliorated IS-induced EMT of renal tubular cells (Figure 10). However, IS-induced apoptosis of renal tubular cells was inhibited by PD98059 or SB203589 (Figure 11).

\section{DISCUSSION}

In this study, we have demonstrated that IS per se induced EMT and apoptotic cell death of renal tubular cells with an activation of ERK1/2 and p38 MAPK. MAPK activation by IS was responsible for apoptosis of renal tubular cells; however, it was not related to IS-induced EMT.

IS, one of the important uremic toxins, is universally elevated in patients with an impaired renal function as it is mainly eliminated by renal tubular secretion. ${ }^{1}$ In patients with decreased glomerular filtration rate (CKD stage 4 or 5), IS level is increased to $8-10 \mu \mathrm{g} / \mathrm{ml},{ }^{15}$ and ESRD patients on maintenance dialysis showed higher levels of IS with the mean and maximal concentrations being approximately 50 and $240 \mu \mathrm{g} / \mathrm{ml}$, respectively. ${ }^{16}$ Although IS has a low molecular weight $(213.23 \mathrm{kDa})$, most of the currently available dialysis modalities including high-flux dialysis do not remove IS effectively, mainly because of the high rate of binding to albumin (96\%) in the blood. ${ }^{17}$ In this study, we used the concentrations of IS found in CKD patients (6.25$25 \mu \mathrm{g} / \mathrm{ml}$ ) to simulate an in vivo environment ${ }^{17}$ without inducing cytotoxicity of renal tubular cells. IS is not only a marker of renal dysfunction but has also been known to have an important role in the progression of renal damage by the mechanism of induction of inflammatory reaction, an enhanced production of profibrotic cytokines ${ }^{5}$ and reactive oxygen species in endothelial, renal tubular, and mesangial cells. ${ }^{18,19}$ Administration of IS also accelerated the aggravation of renal fibrosis, whereas treatment to decrease IS level resulted in a stabilization of renal function. ${ }^{3,6,20}$

One of the most important findings of this study was an induction of EMT by IS, which was confirmed by morphological transition and cell migration of cultured murine 
a
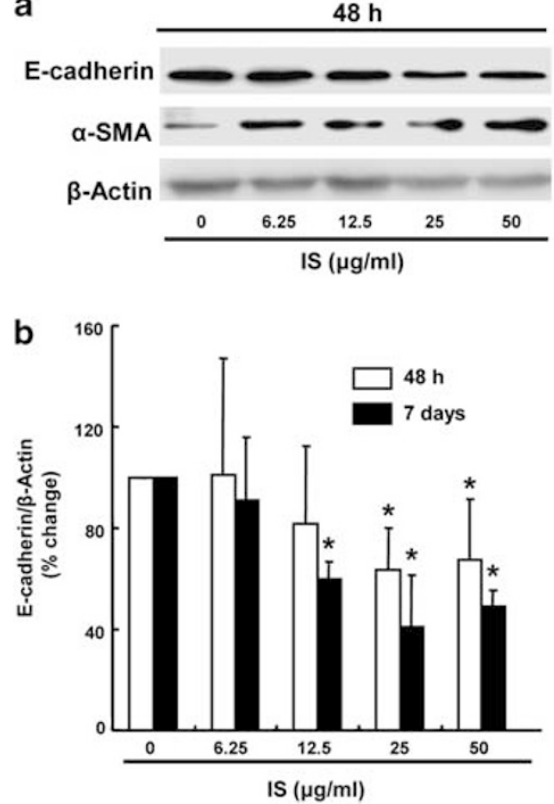

7 days

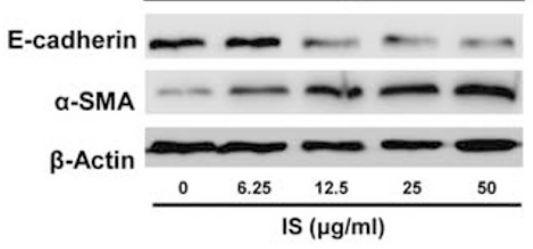

C

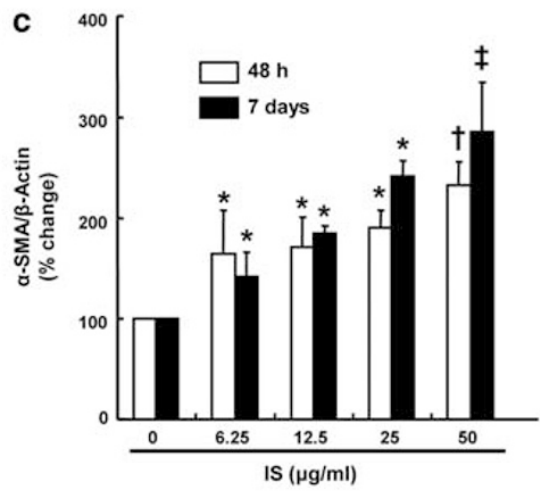

Figure 5 Effect of IS on the expression of E-cadherin and $\alpha$-SMA in NRK-52E cells. Representative western blot demonstrated IS-induced alteration in E-cadherin and $\alpha$-SMA (a). IS induced a significant decrease in E-cadherin (b) and an increase in $\alpha$-SMA (c) at $48 \mathrm{~h}$ (open bars) and 7 days (closed bars) in a dose-dependent manner $(N=5)$. ${ }^{*} P<0.05 \mathrm{vs} 0 \mu \mathrm{g} / \mathrm{ml}$ of IS at each time point; ${ }^{\dagger} P<0.05 \mathrm{vs} 0-12.5 \mu \mathrm{g} / \mathrm{ml}$ of IS at $48 \mathrm{~h}$; ${ }^{\ddagger} P<0.05 \mathrm{vs} 0-25 \mu \mathrm{g} / \mathrm{ml}$ of IS at 7 days.
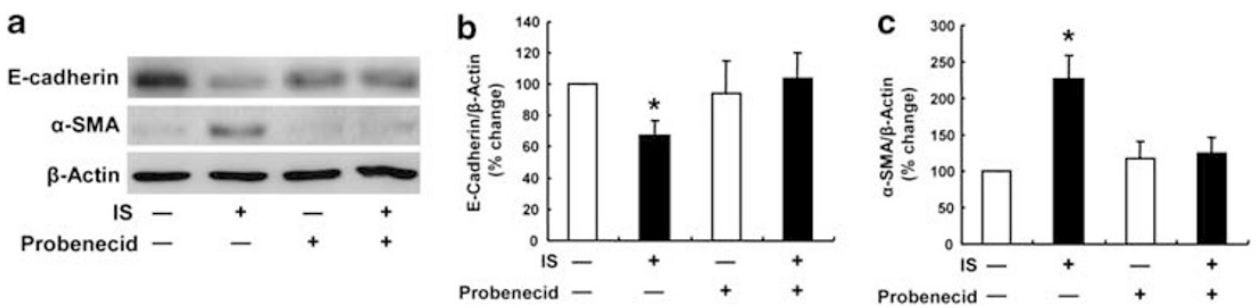

Figure 6 Effect of probenecid on IS-induced changes in the expression of E-cadherin and $\alpha$-SMA protein in NRK-52E cells. Representative western blot analysis (a) and its quantitative analysis (b, c) demonstrated IS-induced alteration in E-cadherin and $\alpha$-SMA was blocked by probenecid ( $1 \mathrm{mM})$ at $48 \mathrm{~h}$ $(N=5) .{ }^{\star} P<0.05$ vs others.
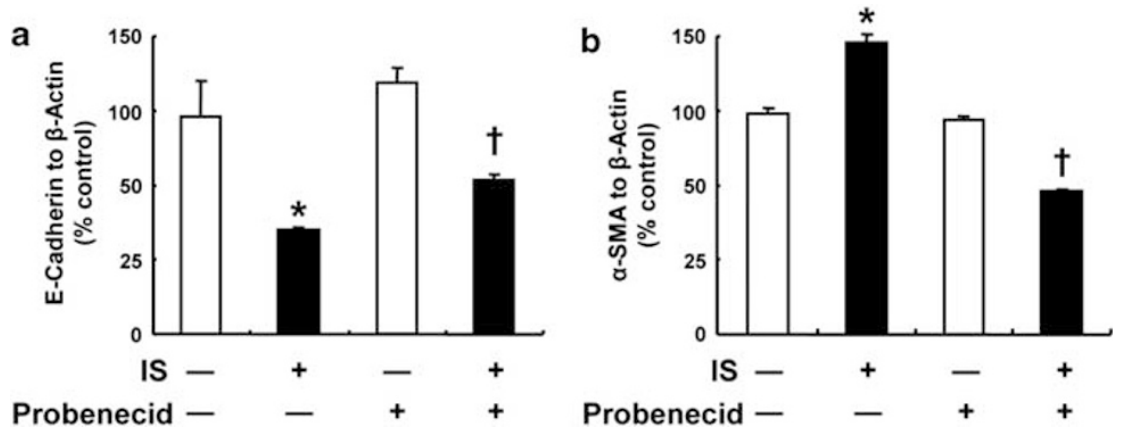

Figure 7 Effect of probenecid on IS-induced changes in the expression of E-cadherin and $\alpha$-SMA mRNA in NRK-52E cells. IS at a concentration of $25 \mu \mathrm{g} / \mathrm{ml}$ significantly reduced relative transcripts of E-cadherin mRNA (a) and increased relative transcripts of $\alpha$-SMA mRNA (b). Pretreatment of probenecid significantly blocked IS-induced changes $(N=4) .{ }^{*} P<0.05$ vs others. ${ }^{\dagger} P<0.05$ vs IS-treated cells.

proximal tubular cells, as well as an altered expression of epithelial and mesenchymal cell markers. Tubular epithelial cells of the adult kidney are known to transform into mesenchymal phenotype in disease states, undergoing
EMT. ${ }^{11,12}$ The presence of EMT in renal fibrosis was first demonstrated by Strutz et $a l,{ }^{21}$ and confirmed by others in in vivo and in vitro experiments. ${ }^{22,23}$ Various stimuli such as high glucose, profibrotic cytokines, and inflammatory 

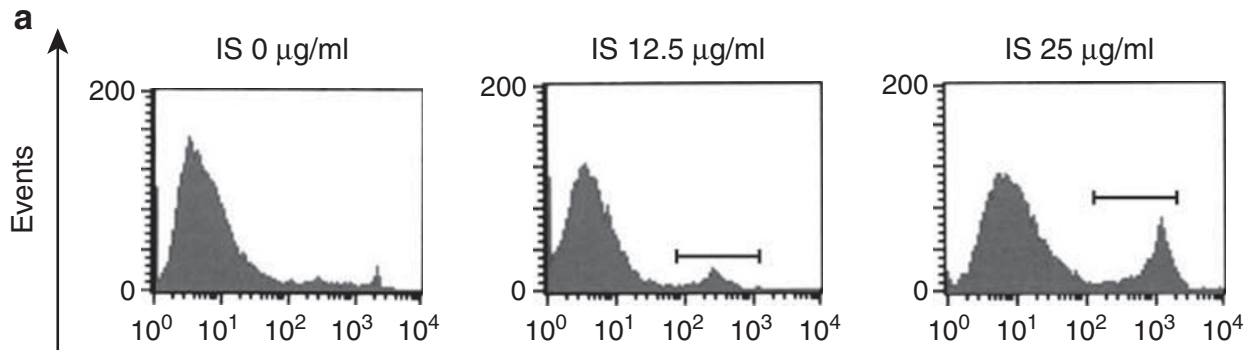

IS $25+$ Probenecid
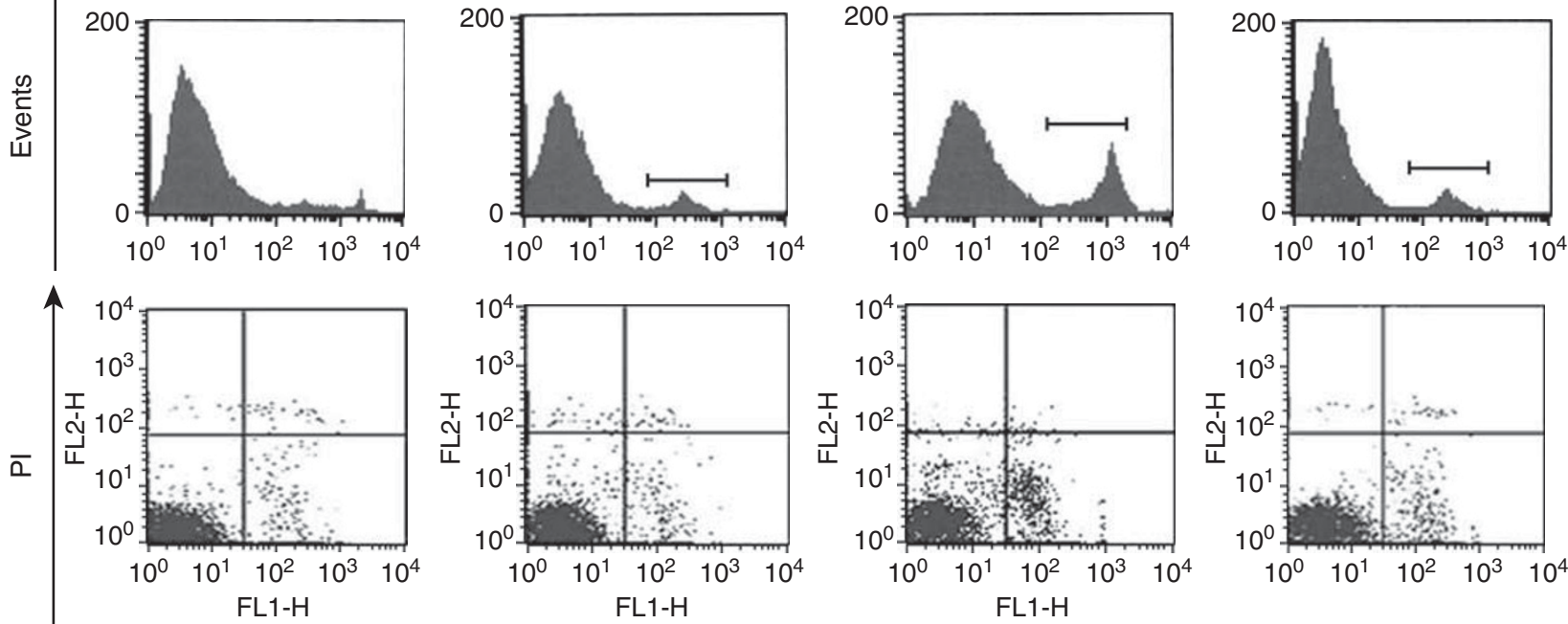

Annexin V-FITC fluorescence

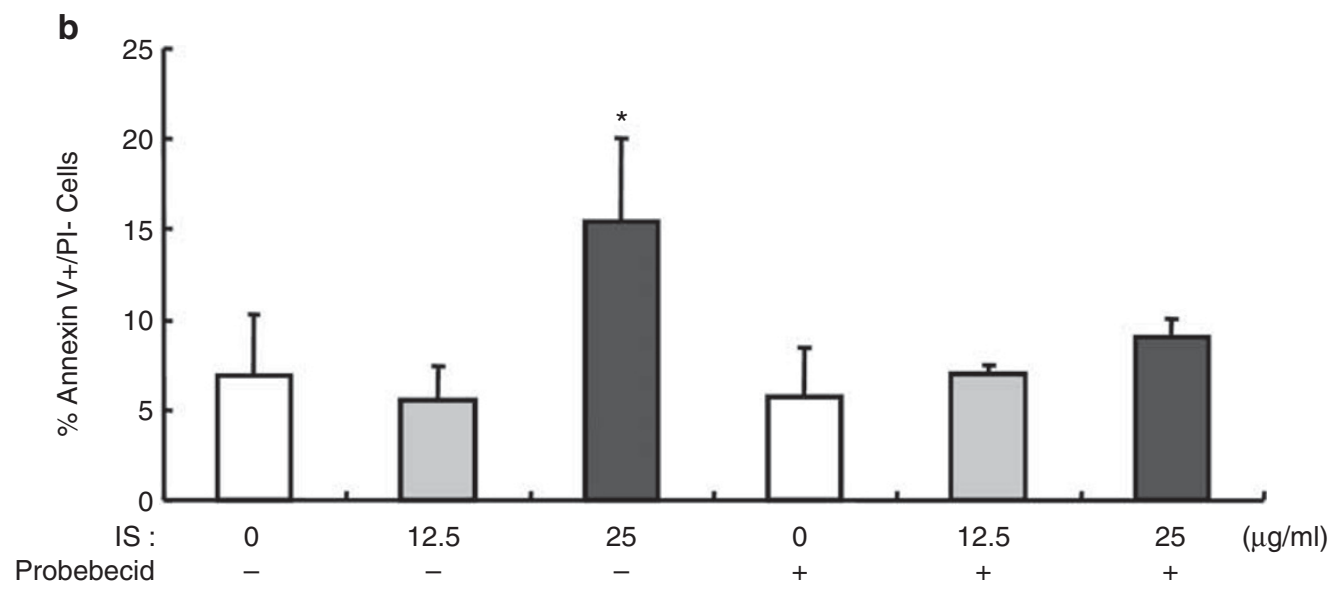

Figure 8 Effect of IS on apoptosis of NRK-52E cells. Early and late apoptotic cells were analyzed with annexin V-propidium iodide staining by flow cytometric analysis. Representative histogram (upper row, a) and dot blots (lower row, a) depicts shifts in fluorescence intensity of annexin $\mathrm{V}$ binding to population of NRK-52E cells and the fractions of annexin V/PI-stained cells, respectively, at $48 \mathrm{~h}$ of IS stimulation $(0,12.5$, and $25 \mu \mathrm{g} / \mathrm{ml})$. Fractions of early apoptotic cells significantly increased in cells treated with $25 \mu \mathrm{g} / \mathrm{ml}$ of IS compared with untreated groups $(P<0.05)$, which was significantly decreased with pre-treatment of probenecid $(\mathbf{b}) .(N=5),{ }^{*} P<0.05$ vs others.

mediators trigger signals to activate transcription factors of tubular epithelial cells, which in turn induce phenotypic transformation. ${ }^{24}$ EMT is characterized by a decrease in the expressions of E-cadherin and ZO-1 protein and an acquisition of de novo $\alpha$-SMA expression. In our study, IS-induced EMT was observed as early as $48 \mathrm{~h}$ of stimulation, and blocked by the OAT, probenecid, suggesting that IS per se entering into cells was responsible for EMT. Furthermore, $\alpha$-SMA expression was increased from a concentration of as low as $6.25 \mu \mathrm{g} / \mathrm{ml}$, at which minimal morphological changes were also noted under the microscope. It is necessary to understand that there are controversies regarding the role of EMT in renal fibrosis mainly due to equivocal in vivo evidence of EMT. ${ }^{12}$ Nonetheless, there was a growing body of evidence supporting the role of EMT in renal fibrosis using cell fate tracing study $y^{25}$ or in vitro experiment. ${ }^{23,26}$ Given the consideration of EMT as a continuous process not always a complete process to formation of myofibroblasts, our data clearly demonstrated the direct effect of IS on EMT expressed as a phenotypic transition into mesenchymal cells and an increase in migration of renal tubular cells. This is consistent with the results of a recent study in animal model of chronic tubulointerstitial fibrosis, demonstrating the beneficial effect of AST-120, an oral adsorbent of uremic toxin including IS, on renal fibrosis. ${ }^{27}$ AST-120 treatment resulted in an amelioration of EMT of renal tubular cells associated with a decrease in serum IS level.

A second novel finding of this study was that IS inhibited the proliferation with an induction of apoptosis. An inhibitory effect of IS on proliferation of proximal tubular 
a
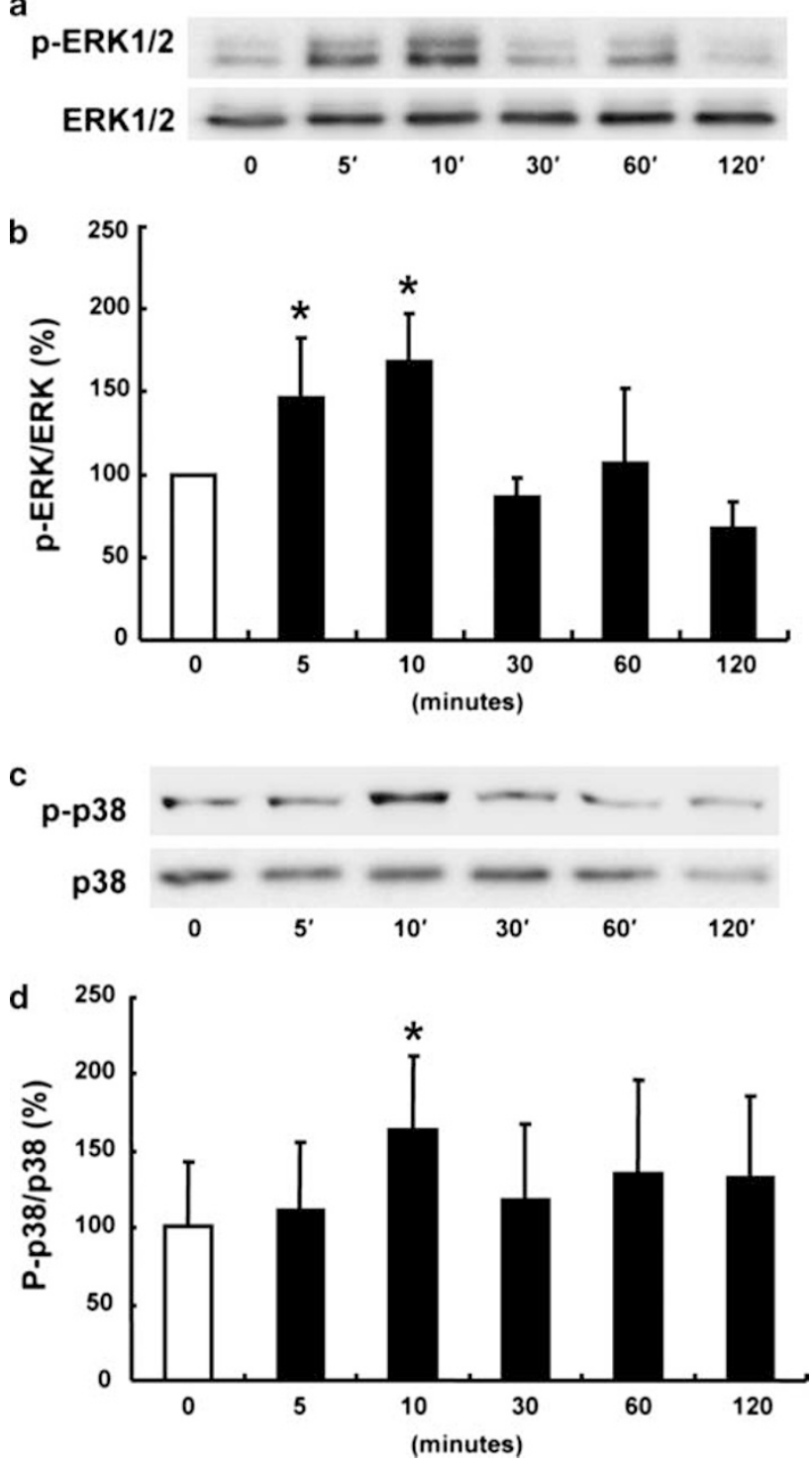

Figure 9 Effect of IS on MAPkinase activation in NRK-52E cells. Representative western blot and its quantitation analysis demonstrated ISinduced phosphorylation of ERK1/2 (a, b) and p38 MAPkinase (c, d) at 5 and 10 min of stimulation, respectively. $(N=5),{ }^{\star} P<0.05$ vs others.

cells was found at a relatively low concentration of $6.25 \mu \mathrm{g} / \mathrm{ml}$ in $48 \mathrm{~h}$ of stimulation, whereas cell cytotoxicity was detected at a high concentration $(125 \mu \mathrm{g} / \mathrm{ml})$. IS also induced apoptosis of renal tubular cells as early as $48 \mathrm{~h}$ at higher concentrations than those inducing EMT. Both apoptosis and inhibition of cell proliferation denote an impaired regeneration or recovery after injury. Although apoptosis is an active process of programmed cell death that is essential to the homeostasis of cell mass, ${ }^{13}$ tubular epithelial cell death, mainly through apoptosis, is an early and consistent finding in progressive renal failure. Many experimental studies have demonstrated a role of apoptosis of renal cells as a mediator of renal disease progression in crescentic glomerulonephritis, a

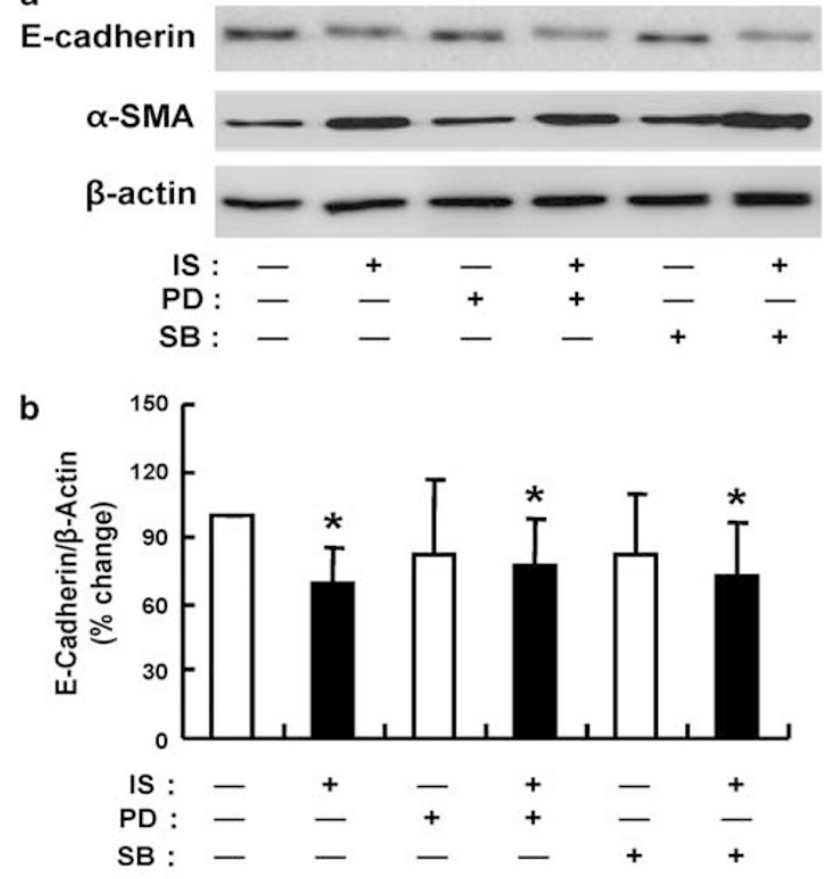

C

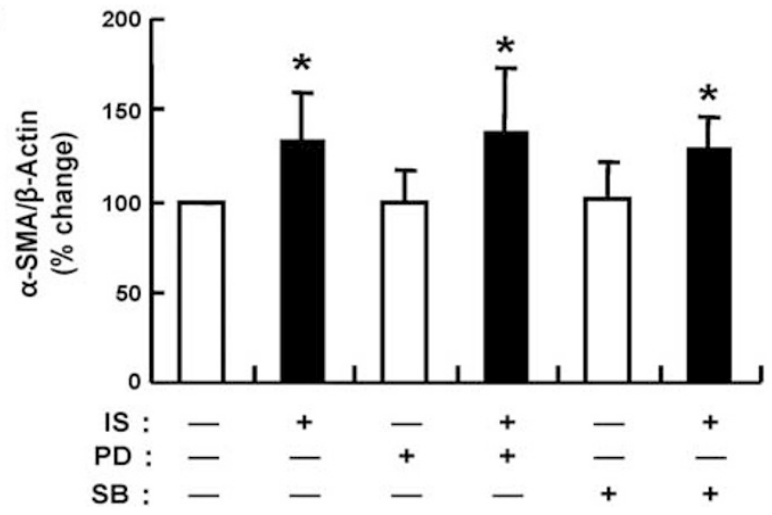

Figure 10 Effect of MAPkinase activation on IS-induced EMT.

Representative western blot (a) and its quantitation analysis (b, c) demonstrated that treatment of MAPkinase inhibitors, PD98059 (PD, an inhibitor of ERK1/2 MAPK, $10 \mu \mathrm{M}$ ) or SB20358 (SB, an inhibitor of p38 MAPK, $10 \mu \mathrm{M})$ induced no substantial effects on IS $(25 \mu \mathrm{g} / \mathrm{ml})$-induced EMT. $(N=5)$, ${ }^{*} P<0.05$ vs control without IS.

obstructive nephropathy, and polycystic kidney diseases. ${ }^{28-30}$ On the basis of our in vitro data in NRK cells exposed to IS for $48 \mathrm{~h}$, IS induced EMT at concentrations from 6.25 to $50 \mu \mathrm{g} / \mathrm{ml}$ and early apoptosis at 25 and $50 \mu \mathrm{g} / \mathrm{ml}$ of IS. Early apoptosis observed in IS-stimulated cells was not associated with a significant cytotoxicity expressed as an increase in LDH release. Stimulation of NRK cells with higher concentrations of IS resulted in late apoptosis without inducing EMT. These findings suggested an induction of EMT and/or apoptosis in IS-stimulated cells might depend on the dose of IS exposure. There are several cytokines or growth factors including TGF- $\beta$, which are known to induce both EMT and apoptosis of epithelial cells. Yang et $a l^{31}$ reported that 

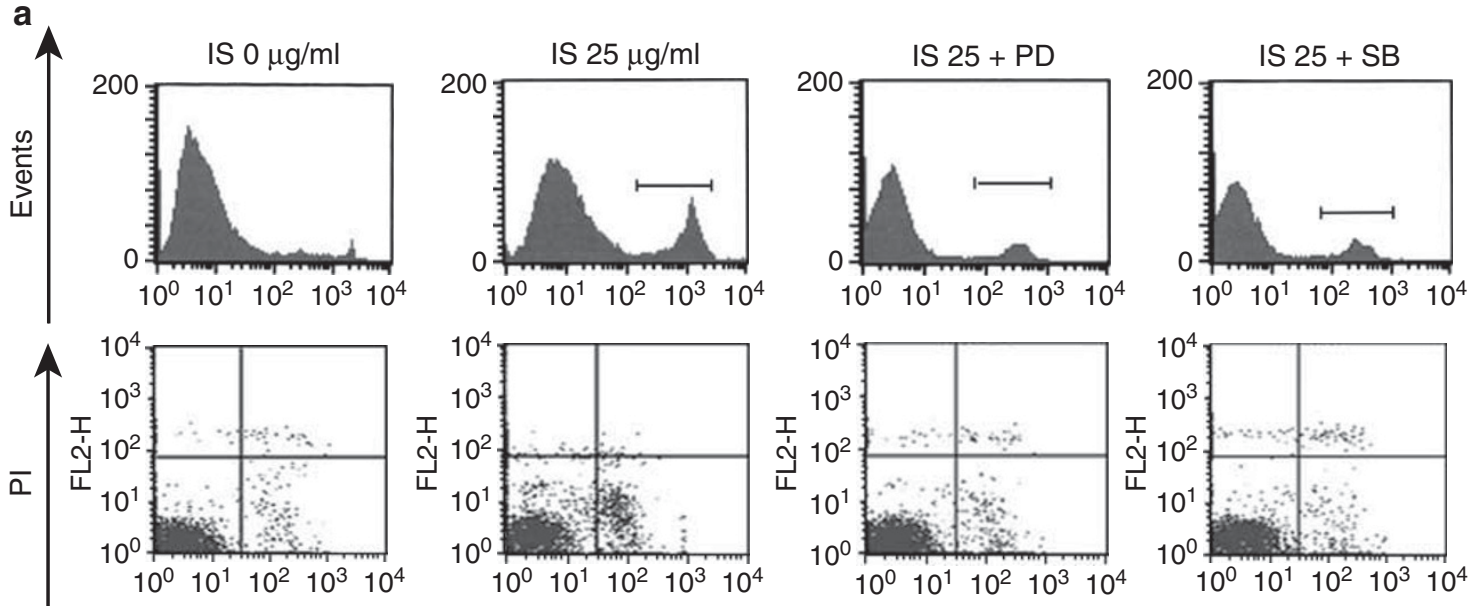

Annexin V-FITC fluorescence

b

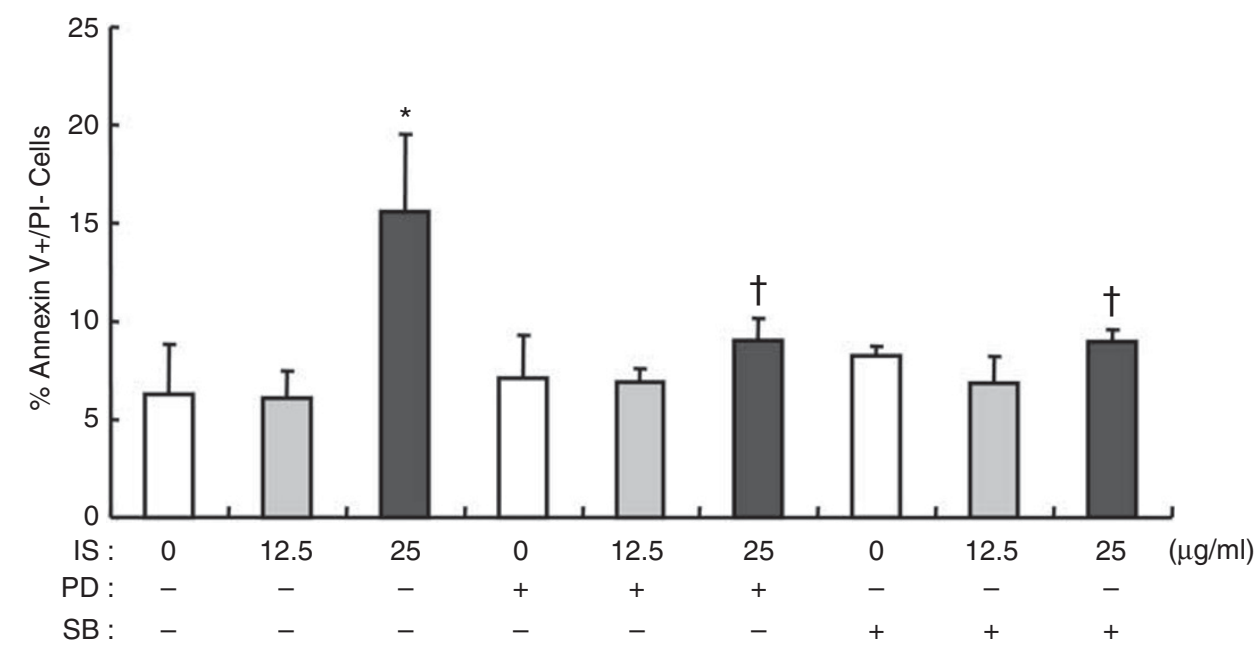

Figure 11 Effect of MAPkinase activation on IS-induced apoptosis. Representative histogram (upper row, a) and dot blots (lower row, a) showed fluorescence intensity distribution of annexin V binding and the fractions of annexin V/PI-stained cells after $48 \mathrm{~h}$ of IS stimulation $(0$ and $25 \mu \mathrm{g} / \mathrm{ml})$ with or without pre-treatment of MAPkinase inhibitor (PD98059 (PD), $10 \mu \mathrm{M}$ or SB20358 (SB), $10 \mu \mathrm{M}$ ) (a). Fraction of early apoptotic cells significantly increased in cells treated with $25 \mu \mathrm{g} / \mathrm{ml}$ of IS compared with untreated groups (b). Pre-treatment of MAPkinase inhibitors blocked the $25 \mu \mathrm{g} / \mathrm{ml}$ of IS-induced apoptotic cell death. $(N=5),{ }^{*} P<0.05$ vs others; ${ }^{\dagger} P<0.05 \mathrm{vs} 25 \mu \mathrm{g} / \mathrm{ml}$ of IS without MAPkinase inhibitors.

TGF- $\beta$-induced EMT and apoptosis in AML 12 cells developed through a cell cycle-dependent mechanism, although it does not seem to be an explanation of cell response to IS in our study as we always synchronized the cell cycle of NRK cells by 48 -h serum starvation.

The next important finding is related to the role of MAPK activation of IS-induced EMT and apoptosis. Although IS clearly activated ERK1/2 and p38 MAPK from 5 min of stimulation, phosphorylation of these MAPKs does not seem responsible for IS-induced EMT, as evidenced by no effect of PD98059 and SB203580 on IS-induced alteration in E-cadherin and $\alpha$-SMA expressions. In contrast, inhibitors of MAPK significantly ameliorated IS-induced apoptosis of NRK-52E cells. Francescato et $a l^{32}$ reported that the blockade of p38 MAPK activation is associated with reduction of the inflammatory process, oxidative stress, and apoptotic cell death in cisplatin-induced renal damage. Ciglitazoneinduced cell death was also reduced by transfection of smallinterfering RNA of p38 MAPK, indicating involvement of p38 MAPK in ciglitazone-induced cell death. ${ }^{33}$ Transient transfection of cells with constitutive active MEK1, which is an upstream kinase of ERK1/2, increased cisplatin-induced apoptosis. ${ }^{34}$ The differential effect of the MAPK inhibitors on EMT and cell apoptosis of renal tubular cells indicated that an activation of MAPK might differentially participate in IS-induced changes in cell phenotype and death. Hashimoto et $a l^{35}$ reported that a specific inhibitor of the JNK signaling pathway but not an inhibitor of ERK1/2 or p38 MAPK attenuated TGF- $\beta 1$-induced phenotypic modulation of human lung fibroblasts. Further studies will be necessary to 
examine an activation of another signal transduction pathway, which may be potentially responsible for IS-induced EMT of renal tubular cells.

Limitation of this study included the in vitro nature of the experimental setup used. However, a recently published in vivo study examining the effect of IS-lowering therapy on renal fibrosis in a rat model of chronic cyclosporine nephropathy also raised the question regarding a possible role of IS involved in the protective effect of AST-120 on EMT and apoptosis. ${ }^{27}$ It was mainly because AST-120 decreased the serum level of other uremic toxins and IS. Therefore, in vivo study actually provided only indirect evidence of IS-induced EMT and apoptosis in renal tubular cells, and introduced substantial complexity in data interpretation. After a recognition of IS as a player of renal disease progression, there have been substantial data investigating the mechanism of IS-induced renal fibrosis, which include an aggravation of renal hypoxia, ${ }^{36,37}$ an induction of endoplasmic reticulum stress demonstrated by an increased expression of C/EBP homologous protein $(\mathrm{CHOP}),{ }^{38}$ and a production of profibrotic cytokines such as TGF- $\beta$ and NF- $\kappa \mathrm{B} .{ }^{39}$ Interestingly, all of these mechanisms are known to induce EMT and apoptosis of renal tubules. Therefore, our findings may provide another rationale for lowering IS in CKD patients to halt the progression of renal disease. Nonetheless, we also need to recognize that not all clinical studies showed a beneficial effect of AST-120 in terms of renal progression, ${ }^{40}$ despite an impressing effect in several human studies in the early and late stages of CKD. ${ }^{8,41}$ This may be related to the diversity of risk factors with complex interaction among factors in the aggravation of renal disease.

In conclusion, our data suggested phenotypic transformation and apoptosis as novel mechanisms of IS-induced renal damage. To the best of our knowledge, this study is the first to show the IS-induced EMT and apoptotic cell death in cultured renal tubular cells. Further studies are necessary to examine whether these two mechanisms are also evident in animal models of CKD and to see the effect of IS-lowering therapy on EMT and apoptosis of the kidney.

\section{ACKNOWLEDGEMENTS}

This work was supported by the National Research Foundation of Korea (NRF) Grant funded by the Korea Government (MEST) (2010-0000185 and 2010-0019866).

\section{DISCLOSURE/CONFLICT OF INTEREST}

The authors declare no conflict of interest.

1. Vanholder R, De Smet R. Pathophysiologic effects of uremic retention solutes. J Am Soc Nephrol 1999;10:1815-1823.

2. Deguchi $T$, Ohtsuki $S$, Otagiri $M$, et al. Major role of organic anion transporter 3 in the transport of indoxyl sulfate in the kidney. Kidney Int 2002;61:1760-1768.

3. Niwa T, Ise M. Indoxyl sulfate, a circulating uremic toxin, stimulates the progression of glomerular sclerosis. J Lab Clin Med 1994;124:96-104.

4. Taki K, Nakamura S, Miglinas M, et al. Accumulation of indoxyl sulfate in OAT1/3-positive tubular cells in kidneys of patients with chronic renal failure. J Ren Nutr 2006;16:199-203.
5. Miyazaki $\mathrm{T}$, Ise $\mathrm{M}$, Seo $\mathrm{H}$, et al. Indoxyl sulfate increases the gene expressions of TGF-beta 1, TIMP-1 and pro-alpha 1(I) collagen in uremic rat kidneys. Kidney Int Suppl 1997;62:S15-S22.

6. Niwa T, Ise M, Miyazaki T. Progression of glomerular sclerosis in experimental uremic rats by administration of indole, a precursor of indoxyl sulfate. Am J Nephrol 1994;14:207-212.

7. Niwa T, Aoyama I, Takayama F, et al. Urinary indoxyl sulfate is a clinical factor that affects the progression of renal failure. Miner Electrolyte Metab 1999;25:118-122.

8. Nakamura $\mathrm{T}$, Kawagoe $\mathrm{Y}$, Ueda $\mathrm{Y}$, et al. Effects of oral adsorbent AST-120 in patients with chronic renal failure with or without diabetes. Ren Fail 2004;26:99-101.

9. Schulman $G$, Agarwal $R$, Acharya $M$, et al. A multicenter, randomized, double-blind, placebo-controlled, dose-ranging study of AST-120 (Kremezin) in patients with moderate to severe CKD. Am J Kidney Dis 2006;47:565-577.

10. Motojima $M$, Hosokawa $A$, Yamato $H$, et al. Uremic toxins of organic anions up-regulate PAl-1 expression by induction of NF-kappaB and free radical in proximal tubular cells. Kidney Int 2003;63:1671-1680.

11. Liu Y. Epithelial to mesenchymal transition in renal fibrogenesis: pathologic significance, molecular mechanism, and therapeutic intervention. J Am Soc Nephrol 2004;15:1-12.

12. Zeisberg M, Duffield JS. Resolved: EMT produces fibroblasts in the kidney. J Am Soc Nephrol 2010;21:1247-1253.

13. Ortiz A, Lorz C, Justo $P$, et al. Contribution of apoptotic cell death to renal injury. J Cell Mol Med 2001;5:18-32.

14. Yu MA, Shin KS, Kim JH, et al. HGF and BMP-7 ameliorate high glucoseinduced epithelial-to-mesenchymal transition of peritoneal mesothelium. J Am Soc Nephrol 2009;20:567-581.

15. Barreto FC, Barreto DV, Liabeuf $S$, et al. Serum indoxyl sulfate is associated with vascular disease and mortality in chronic kidney disease patients. Clin J Am Soc Nephrol 2009;4:1551-1558.

16. Vanholder R, De Smet R, Glorieux $G$, et al. Review on uremic toxins: classification, concentration, and interindividual variability. Kidney Int 2003:63:1934-1943.

17. Lesaffer $\mathrm{G}$, De Smet $\mathrm{R}$, Lameire $\mathrm{N}$, et al. Intradialytic removal of proteinbound uraemic toxins: role of solute characteristics and of dialyser membrane. Nephrol Dial Transplant 2000;15:50-57.

18. Gelasco AK, Raymond JR. Indoxyl sulfate induces complex redox alterations in mesangial cells. Am J Physiol Renal Physiol 2006;290: F1551-F1558.

19. Dou L, Jourde-Chiche N, Faure V, et al. The uremic solute indoxyl sulfate induces oxidative stress in endothelial cells. J Thromb Haemost 2007:5:1302-1308.

20. lida S, Kohno K, Yoshimura J, et al. Carbonic-adsorbent AST-120 reduces overload of indoxyl sulfate and the plasma level of TGF-beta1 in patients with chronic renal failure. Clin Exp Nephrol 2006;10: 262-267.

21. Strutz F, Muller GA, Neilson EG. Transdifferentiation: a new angle on renal fibrosis. Exp Nephrol 1996;4:267-270.

22. Ng YY, Huang TP, Yang WC, et al. Tubular epithelial-myofibroblast transdifferentiation in progressive tubulointerstitial fibrosis in $5 / 6$ nephrectomized rats. Kidney Int 1998;54:864-876.

23. Yang J, Liu Y. Blockage of tubular epithelial to myofibroblast transition by hepatocyte growth factor prevents renal interstitial fibrosis. J Am Soc Nephrol 2002;13:96-107.

24. Acloque $\mathrm{H}$, Adams MS, Fishwick $\mathrm{K}$, et al. Epithelial-mesenchymal transitions: the importance of changing cell state in development and disease. J Clin Invest 2009;119:1438-1449.

25. Iwano $M$, Plieth $D$, Danoff $T M$, et al. Evidence that fibroblasts derive from epithelium during tissue fibrosis. J Clin Invest 2002;110: 341-350.

26. Yang J, Liu Y. Dissection of key events in tubular epithelial to myofibroblast transition and its implications in renal interstitial fibrosis. Am J Pathol 2001;159:1465-1475.

27. Kim SH, Ghee JY, Piao S, et al. Early and delayed effects of AST-120 on chronic cyclosporine nephropathy. Nephrol Dial Transplant 2011; 26:1502-1515.

28. Murcia NS, Sweeney Jr WE, Avner ED. New insights into the molecular pathophysiology of polycystic kidney disease. Kidney Int 1999;55: 1187-1197.

29. Shimizu A, Masuda $\mathrm{Y}$, Kitamura $\mathrm{H}$, et al. Apoptosis in progressive crescentic glomerulonephritis. Lab Invest 1996;74:941-951. 
30. Truong LD, Petrusevska G, Yang G, et al. Cell apoptosis and proliferation in experimental chronic obstructive uropathy. Kidney Int 1996:50:200-207.

31. Yang $Y$, Pan $X$, Lei $W$, et al. Transforming growth factor-beta1 induces epithelial-to-mesenchymal transition and apoptosis via a cell cycledependent mechanism. Oncogene 2006;25:7235-7244.

32. Francescato HD, Costa RS, da Silva CG, et al. Treatment with a p38 MAPK inhibitor attenuates cisplatin nephrotoxicity starting after the beginning of renal damage. Life Sci 2009;84:590-597.

33. Kwon $\mathrm{CH}$, Park JY, Kim TH, et al. Ciglitazone induces apoptosis via activation of p38 MAPK and AIF nuclear translocation mediated by reactive oxygen species and $\mathrm{Ca}(2+)$ in opossum kidney cells. Toxicology 2009;257:1-9.

34. Kim $\mathrm{YK}, \mathrm{Kim} \mathrm{HJ}$, Kwon $\mathrm{CH}$, et al. Role of ERK activation in cisplatininduced apoptosis in OK renal epithelial cells. J Appl Toxicol 2005; 25:374-382.

35. Hashimoto S, Gon Y, Takeshita I, et al. Transforming growth factorbeta1 induces phenotypic modulation of human lung fibroblasts to myofibroblast through a c-Jun-NH2-terminal kinase-dependent pathway. Am J Respir Crit Care Med 2001;163:152-157.
36. Yu M, Kim YJ, Kang DH. Indoxyl sulfate-induced endothelial dysfunction in patients with chronic kidney disease via an induction of oxidative stress. Clin J Am Soc Nephrol 2011;6:30-39.

37. Palm F, Nangaku M, Fasching A, et al. Uremia induces abnormal oxygen consumption in tubules and aggravates chronic hypoxia of the kidney via oxidative stress. Am J Physiol Renal Physiol 2010;299: F380-F386.

38. Kawakami T, Inagi R, Wada T, et al. Indoxyl sulfate inhibits proliferation of human proximal tubular cells via endoplasmic reticulum stress. Am J Physiol Renal Physiol 2010;299:F568-F576.

39. Satoh $M$, Hayashi $H$, Watanabe $M$, et al. Uremic toxins overload accelerates renal damage in a rat model of chronic renal failure. Nephron Exp Nephrol 2003;95:e111-e118.

40. Akizawa T, Asano Y, Morita S, et al. Effect of a carbonaceous oral adsorbent on the progression of CKD: a multicenter, randomized, controlled trial. Am J Kidney Dis 2009;54:459-467.

41. Konishi K, Nakano S, Tsuda S, et al. AST-120 (Kremezin) initiated in early stage chronic kidney disease stunts the progression of renal dysfunction in type 2 diabetic subjects. Diabetes Res Clin Pract 2008;81:310-315. 